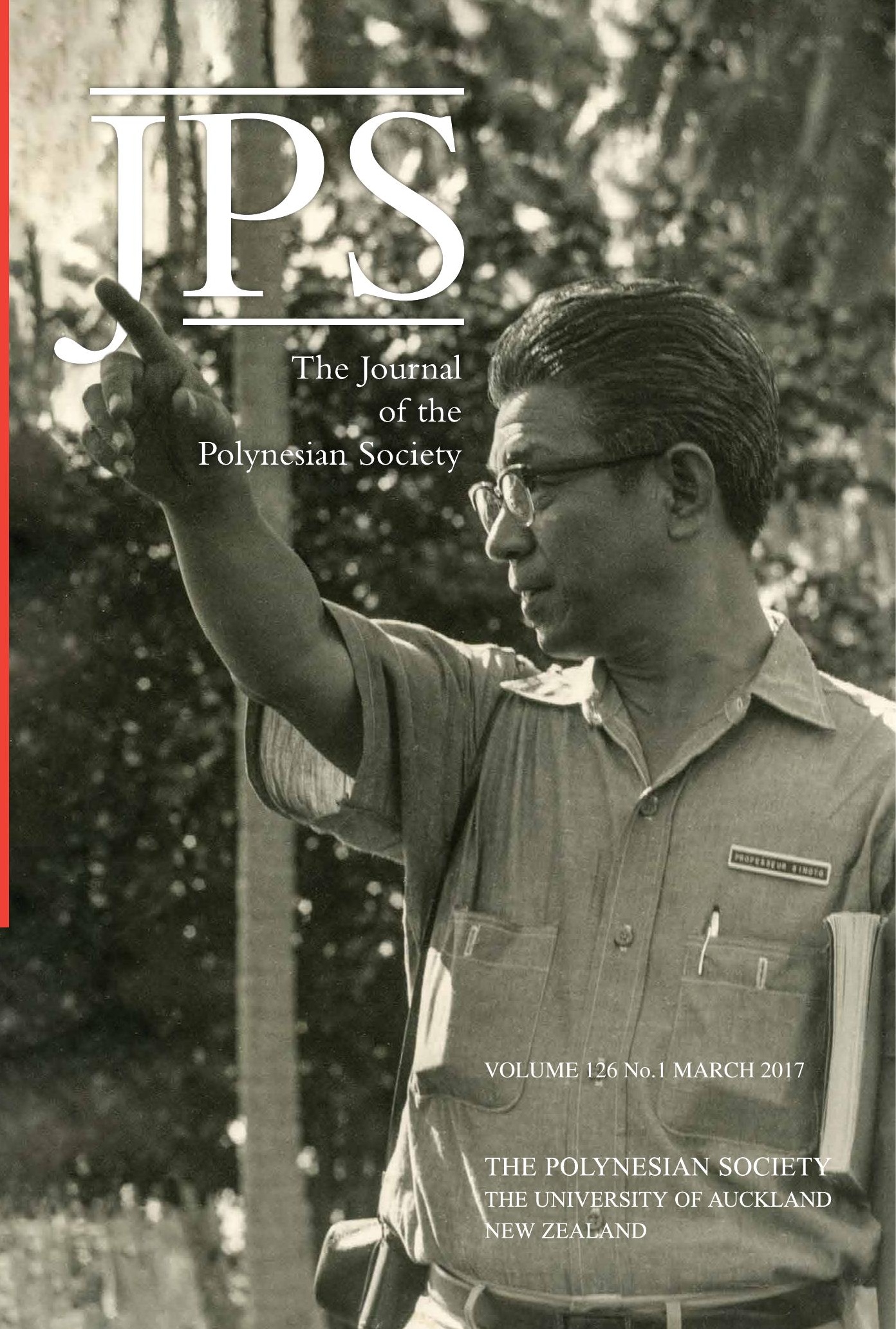




\title{
COSMOLOGY AND STRUCTURE: THE TÄHUHU IN THE 19TH-CENTURY WHARE MĀORI
}

\author{
JEREMY TREADWELL \\ University of Auckland
}

The tāhuhu is the ridgepole of the traditional Māori house or whare. It is a single beam that typically spans the length of the building, integrating the entire articulated timber frame. The tāhuhu is the New Zealand manifestation of a ubiquitous Polynesian building system that features ridge-beams and supporting posts (Austin 2001: 11-13). It has been detected archaeologically in both large and small pre-European houses (Leach et al. 2000: 94-95) and is strikingly present in the surviving large-scale meeting houses of the 19th century. This paper considers the tähuhu both in the process of building and in its continuing role in the stability of the physical and social structure of the house. It is written largely from an architectural viewpoint, a viewpoint informed by the materiality and geometries of whare components resident in museums, and those that form part of whare in extant marae 'meeting grounds, community centre' complexes. The arguments here are also developed from the narratives and imagery of history, and the written and oral accounts of Māori ancestry and technology.

Māori construction of increasingly large wharenui 'meeting houses' in the second half of the 19th century was an architectural manifestation of wider concerns held by Māori about the loss of land and the threat of military action, both of which affected Māori culture in fundamental ways (Neich [1994] 2011: 110-11; Walker 2007: 167). House development also responded to meet the needs of missionary-led Christian rituals and subsequently of indigenous expressions of Christian worship that were seen as more relevant to some Māori.

As the meeting house became an object of group identity and pride it developed complex systems of representation to anchor the genealogical and social worlds of the hap $\bar{u}$ 'subtribe'. It is well known that in this sense, the meeting house allowed each person to trace their whakapapa 'genealogy' back to the origins of the space and light of the world - Te Ao Mārama. The interior of the whare became a metaphor for this foundational event, its interior constituting the inhabitable space of the world cleaved open by the god Tāne, who forced apart the embrace of Ranginui, the sky father, from Papatūānuku, the earth mother. In this built metaphor the roof of the whare is Ranginui, the floor is Papatūānuku and Tāne is the prop that separated them (Sadler 2014: 1440). ${ }^{1}$ 
This paper is concerned with the role of the tähuhu in the structure and construction of the 19th-century whare, not simply as a predictable technical accomplishment but as a cultural construction that sits in complex relationship with the representational art practices for which the whare is well known. In this analysis, Māori tectonics are aligned with the Māori creation narrative: Te Ao Mārama becomes the structural prescription of the whare Māori-cosmology, whakapapa and structure inseparably fused both in physical composition and in the esoteric and inaccessible knowledge of the whare wānanga 'traditional house of learning' (Hone Sadler pers. comm. 2013). Equally inaccessible to this enquiry into Māori tectonics is the craft knowledge of the tohunga 'expert'. Unpublished and largely unknown to those not inculcated into its knowledge and practices, this commentary on the concepts and narratives underpinning the practices of construction remain obscure. Professor Ranginui Walker described the master carver Paki Harrison's 20th-century nocturnal inculcation into the lore of the wänanga by his mentor Pine Taiapa. He explained the individual instruction as a practice that formerly took place in the ancestral houses of tribal communities but one that was no longer practiced, due to the dispersal of young men in search of individual work (Walker 2008: 60-61).

To find a way to think about Māori tectonics, this paper has situated a Western epistemology to one side of the Māori conflation of creation cosmology and tectonics. Western engineering practice is born of the discipline of physics, whose core narrative also extends to the creation of matter and the origin of the universe. In contrast to the interrelated epistemologies built into the whare, Western physics, by virtue of its origins in Enlightenment classification, can be excised from the context of its application. Its capacity to be abstractly and theoretically constructed allows for use in design and, as in this paper, in analysis.

This kind of cross-epistemological analysis risks being interpreted as the continuation of the colonial tradition of appropriating and redefining indigenous knowledge. Examples of the process of the colonising and controlling of knowledge can be seen in the translations in Rev. L.W. Williams' 1892 Dictionary of the Maori Language. In this edition we see that the terms for the structures used to raise the tähuhu, 'rangitapu' and 'tokorangi' (references to the Te Ao Mārama separation of Ranginui from Papatūānuku), were translated as functional nouns, 'scaffolding' and 'sheers', thereby excising the cosmological significance embedded in the Māori words. This paper looks to give careful attention to the cultural implications of 19th-century etymology juxtaposed against the functionalist abstraction of Western engineering analysis as applied to the images, narratives and house components that survive from that time. 
Finally, this paper considers the completed whare structure and suggests that the forces composed in sophisticated and surprising relationships are in many ways antithetical to Western structural thinking. It is further argued that this apparent structural otherness has contributed to the colonial tendency to deny indigenous constructional agency.

\section{THE TÄHUHU IN PRINT}

Colonial descriptions of Māori architecture leave the impression that Māori building structures excited little curiosity. Māori buildings have long been the subject of studies in anthropology and art history, which have emphasised carving and other surface arts. More recent examples of this disciplinary focus include the works of Roger Neich (2011[1994]), Deidre Brown (2003), Ngarino Ellis (2016) and Damian Skinner (2016). By contrast, little attention has been paid to the culture of Māori building technology. Between 1896 and1949 analyses of structural concepts were subsumed into accounts of building process - with descriptions of construction sequences substituted for analysis and description of structure. Authors of these descriptions include the Rev. Herbert W. Williams (1896), Augustus Hamilton (1896), Elsdon Best (1924), Makereti (1986 [1938]) and Te Rangi Hiroa (1949). However, these publications drew heavily from each other, sometimes including almost identical phrases, as in Makereti (1986 [1938]: 302) and Best (1924: 565). Similarly, Augustus Hamilton (1896: 81-87) reproduced many of the details of the Williams paper of the same year. Hiroa (1949) referenced the Williams article and Ngata's (1897) subsequent commentary. These restricted publications and their images continued to be referenced throughout the 20th century in general texts on traditional Māori life.

One explanation for this lack of curiosity about Māori structural thinking is that Māori constructions were presumably seen to be, in Western engineering terms, "simply supported" by a post and beam structure in which beams carried gravity loads, which were transferred through supporting posts and dispersed into the ground. Resistance to strong winds and earthquakes was probably attributed, if considered at all, to the action of the posts in the ground as standing cantilevers.

However, in the 1990s at Kohika in the Bay of Plenty, archaeological evidence was uncovered by Geoff Irwin (Irwin et al. 2004) of a pre-contact 18th-century kainga 'village' where some small whare had been constructed with a sophisticated technique by which the structure of the whare was stiffened against lateral forces. The whare were built with transverse lines of structure involving individual poupou 'wall posts' and heke 'rafters' paired across the tâhuhu. (Fig. 1). From the artefacts found at the Kohika site, Irwin 


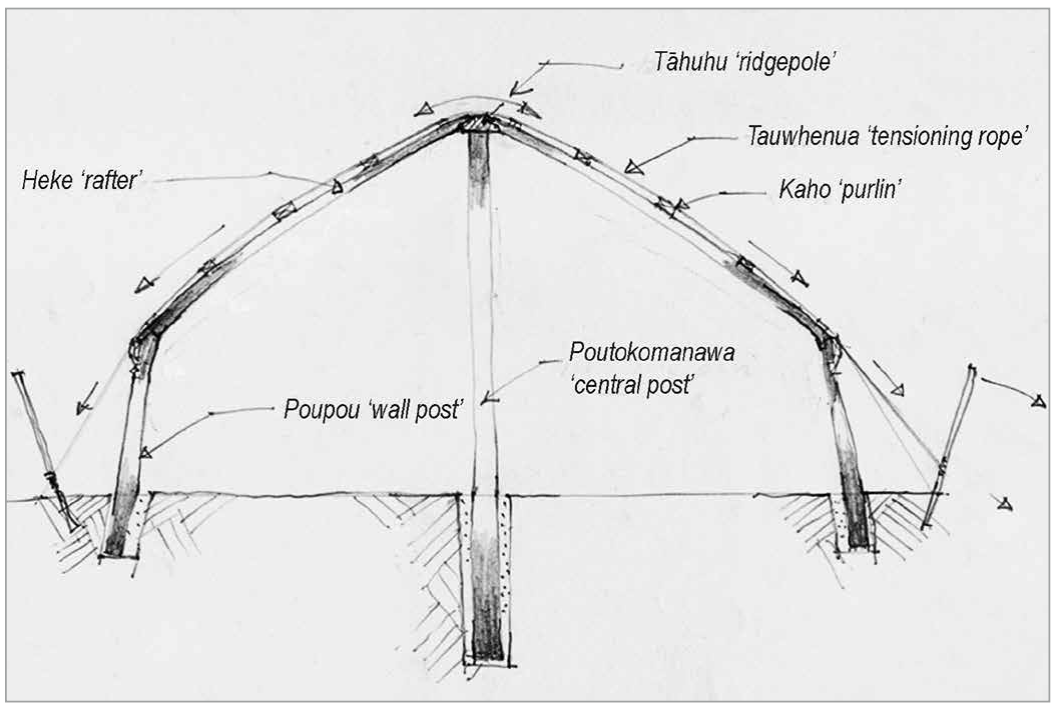

Figure 1. Schematic cross-section of the compressed arched frame of the whare. Drawing by J. Treadwell, 2014.

and colleagues (2004: 122-48) reconstructed the cross-sectional components of the whare as a sequence of transverse frames. From the geometries of lashing holes discovered on the backs of the heke and the poupou, and an unmistakable "shadow" on the timber from a plaited rope, Irwin was able to convincingly demonstrate that the cross-sectional structure of the whare had been post-tensioned.

Each structural frame consisted of opposing, paired poupou and heke, compressed against the tāhuhu with the use of a tauwhenua 'tensioning rope'. The collective action of these arched frames contributed to the formation of a stiff cross-sectional structure. The finds at Kohika were the first physical confirmation of Makereti's (also known as Maggie Papakura) 1930s description of the post-tensioning process in her book Old Time Maori which, until recent times, had remained largely unexamined. However, despite substantiation of the use of post-tensioning, the buildings at Kohika were very small and the implication of Makereti's description was that the process had been applied to larger 19th-century buildings. Her account conveys a real sense of the effort and forces involved when applied to larger buildings:

A short piece of rope was tied to the tuawhenua [sic] described on the previous page, while the other end was tied to the tree trunk to be used as a 
lever. The use of this lever placed a great strain on the rope, and this strain locked the timbers of the house. The two pou opposite each other took the strain, and the rafters were held together on wall and ridgepole. The creaking of timbers was heard under the strain. The end of the tightened rope was tied to the outer strut, and then the lever and short rope were taken away. (Makereti 1986 [1938]: 303)

Despite the obvious indications in the text of the scale of elements and the forces involved, "tree trunks" for levers, "creaking timber" and "great strain", more recent commentary by art historian Richard Sundt expressed doubt about the efficacy of this technology at a large scale. Sundt's (2010: 166) views on this issue extend a 19th-century scepticism of Māori engineering capability, which he elaborates further in an argument that large-scale 19th-century Māori building had been possible essentially because of the uptake of European technology.

This argument has been examined in respect of that particular and primary act in the construction of a whare, that of how 19th-century Māori raised the sometimes massive $t \bar{a} h u h u$ to the top of its supporting posts (Treadwell 2012). In that paper it was proposed that the discourse describing Māori building processes had generally simplified Māori technology by confining considerations to physical and operative parameters and failing to consider that building could also be enacted by the functional integration of social, environmental, cosmological and indigenous knowledge systems. The discussion also proposed that the abstract nature of the machine function that increasingly drove the 19th-century colonial enterprise had had the effect of distancing individuals from the mass and nature of the material world. In The Perception of the Environment: Essays on Livelihood, Dwelling and Skill, anthropologist Tim Ingold (2011: 296) tracked the estrangement that developed between the operative and the artisan with the development of the machine. Ingold cited J. Bruzina who wrote, “...the entire work-action [of the machine] becomes something that can be dealt with independently of the human being in its properties and principles of function" (Bruzina and Wilshire 1982: 170). As individual colonists and commentators became progressively physically and then conceptually isolated from the industrialising and professionalising world, so functionality came to reside, uninterrogated within the machine. Treadwell (2012: 1165) further argued that the emergent industrialising colonial culture was therefore rendered less able and less willing to understand or imagine the sophistication and effectiveness of a coordinated socially-driven indigenous engineering.

It was within this context that Treadwell (2012) assembled evidence that before the arrival and availability of Western technology Māori had in fact developed technologies that could manipulate large-scale infrastructure and potentially the capability of raising tāhuhu in excess of $1100 \mathrm{~kg}$. It was 
also argued that traditional Māori engineering proceeded, not as a machine operation of measureable and predictable outcomes, but as a complex negotiation of relations between their sophisticated technology of the everyday with a continuing presence of a cosmological past. Further, the internal relations within this cultural technology should be seen, as Māori saw them, as both indivisible and performative.

\section{THE TĀHUHU-A CONSTRUCT OF COLLECTIVE ENGINEERING}

Māori capability in large-scale engineering tasks has been documented by Elsdon Best and other ethnographers, most vividly illustrated in the felling and transporting of very large trees (Best 1924: 193-95, 2005 [1927]: 79). As a result of interrogating Best (1924) and applying data to the structures outlined, Treadwell (2012: 1161) argued that Māori had developed a sophisticated lifting technology that had the capacity to raise the longest and heaviest ridge beams in the large whare constructed in the second half of the 19th century (Fig. 2). The technology took advantage of mätauranga Māori 'Māori knowledge,

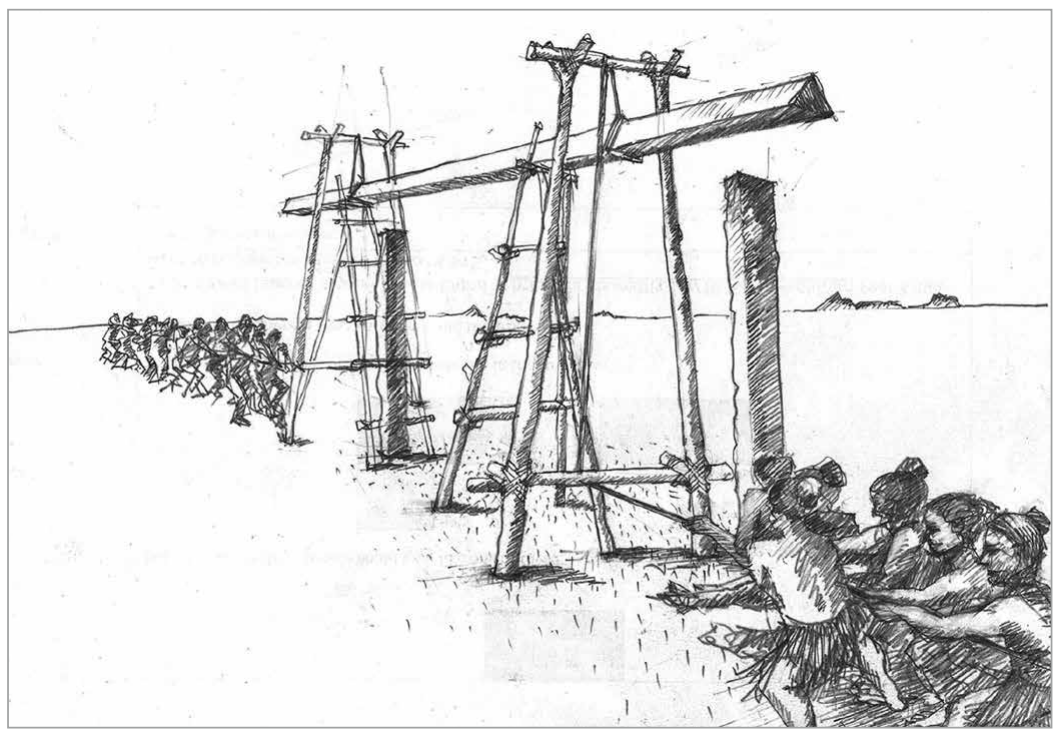

Figure 2. Interpretation of Elsdon Best's (1924) description of the rangitapu. The low horizontal member allowed as many people as were needed to pull the rope horizontally and raise the tăhuhu without excessive over-turning forces. The additional friction was overcome with plant lubricants and extra people pulling the ropes. Drawing by J. Treadwell, 2014. 
understanding', including that of plant lubricants to reduce friction in the mechanism and the deployment of a lifting structure whose geometry allowed for as many men as necessary to participate in the act of raising the tăhuhu.

New Zealand historian and ethnographer James Cowan (1930: 123) wrote of this social capacity for large-scale infrastructural tasks: "In the heart of the Urewera Country, at Mataatua, is the largest whare-whakairo [carved house] of purely Māori construction. It is about 80 feet [c. $24 \mathrm{~m}$ ] in length and 36 feet [c. $11 \mathrm{~m}]$ in width. The raising of the massive ridge-pole, when the house was built for Te Kooti in 1890, engaged the efforts of a hundred men". Seventy men from the 'Ngāti Awa iwi 'tribe, people' were said to have participated in the building of the Mataatua house. There are several other such accounts, including those of Phillipps (1946: 37) and master carver Pine Taiapa, who said with reference to a meeting with Ngāti Whātua about a prospective building in Auckland, "You must have manpower to do it. I was pleased to hear our kaumatua [elders] say in Hicks Bay that Ngāti Whātua have 30,000 people. I can picture the building we put up in Auckland being 120 feet long [36 m], 60 feet wide [18 m], because man-power is there" (Taiapa 1965). In this statement Taiapa explicitly links social participation to building size, a relationship absent from calculations about structural performance and machine function.

\section{THE TĀHUHU IN COSMOLOGY AND REPRESENTATION}

This section considers Māori building structure not as a description of building process or as a theoretical structural model but as a formation of structural relationships given scale, meaning and function consistent with its cosmological origins and genealogical and social purposes. In this context, alignment will be sought between structure and the metaphorical and representational roles necessary for the social and structural stability of the house.

If the technical act of raising the tāhuhu was fuelled by collective endeavour and material and environmental knowledge, it was given meaning through its ritual recapitulation of the Te Ao Mārama construct - the coming of light and knowledge into the world of $i w i$ (Treadwell 2012: 1153). The ritual incantation by a tohunga 'specialist' (priest in this case) of a karakia 'prayer' to raise the tāhuhu was, in this context a mediation between te ao tāngata 'the world of humans' and the realm of atua 'gods'. The necessity for a tohunga to invoke the sanction of atua to raise the tāhuhu was a measure of the physical magnitude and cosmological peril implicit in the task. As the Ngāti Awa rangatira 'chief' Mereana Mokomoko recalled of the construction of the great house Hotunui at Hauraki in 1878, "The first post erected was named after Pereki Awhiowhio, chief of Ngatiwhanaunga. When an attempt was made to lift the ridge-pole it failed: then we sent for Paroto Manutawhiorangi, who uttered an incantation, or karakia, called 'Tehuti o Tainui' (the raising of Tainui), and lo! the great tree was lifted up quickly 
and easily. Such was the power of magic as exercised by Maori priests of old" (Mokomoko 1897: 41).

In the Māori world the tāhuhu is conventionally understood as representing the backbone of the eponymous ancestor in the anthropomorphic house. But its representational role of defining the origin of all ancestral and social relationships within the house is overlaid by the equivalent structural role in which all structural relationships are played out in equivalence to the social relationships which give purpose and life to the house. So, in this sense, the tāhuhu is not a metaphor but a relational element in which structure and genealogy are inseparably intertwined.

Another example of this structural and social equivalence in the whare can be seen in the heke and its connection to poupou. 'Heke' means 'rafter' in Māori but it also means 'to descend' or 'descent' (Ryan 2008: 60; Williams 1892: 26). In the top-down construction of the whare, 'heke' signals the rafters' physical descent from the tāhuhu to the poupou. ${ }^{2}$ In genealogical terms heke could be read as the ancestral descent depicted in the repeating patterns of kōwhaiwhai 'painted geometries representing ancestral history on the underside of the heke'. As Neich (2011 [1994]: 130) summarised, “...the structure of the house constitutes a genealogical plan..." and more specifically, "... the rafters [heke] were equated with branching lines of descent leading down to the ancestral representations of the poupou".

In Māori cosmology the forcible separation of Ranginui from Papatūānuku created the space and light of the world: Te Ao Mārama. In this foundational narrative, Tāne Mahuta, the last of the offspring gods, was finally successful in forcing his parents apart: "It was the fierce thrusting of Tāne which tore the heaven from the earth, so they were rent apart, and darkness was made manifest and so was the light" (Reed 2004: 11). It is in relation to this origin story that the tāhuhu and Tāne can best be understood. In the narrative Tāne interposes himself between Ranginui and Papatūānuku, pushing Ranginui upwards with his legs. Tāne, at this moment, becomes the first element of Māori tectonics - the toko or prop. Specifically, Tāne becomes a tokorangi, literally the prop of Rangi. It was the tokorangi that was later to be used as a prop or trestle to support the tähuhu of the whare during its elevation to the top of the posts (Best 1924: 193-94).

In the early 1871 edition of the Dictionary of the New Zealand Language, toko was translated as both 'a pole to shove with' but also as 'rays of light' (Williams 1871: 152, 204). The implication of the latter is, of course, that these are the rays of light that first shone upon Papatūānuku as Ranginui was forced from her. It is of particular interest then that in anthropologist Donald Tuzin's account of the building of the house Tambaran in the Sepik River area of Papua New Guinea he described the hoisting of the massive ridgepole as always taking place at dawn (Tuzin 1980: 139). 
In the Ngāpuhi (tribe of Northland) narrative of Te Ao Mārama, when Tāne pushed Ranginui from Papatūānuku he then propped his father and mother apart with four prepared poles or toko: one for his feet, two for his armpits and one for his head (Hone Sadler pers. comm. 2013). Sadler describes the interior of the whare and its construction as a metaphor for Te Ao Mārama, in which the roof is Ranginui and floor is Papatūānuku. The raising and propping of the tăhuhu within the whare recapitulates that moment when light and consciousness entered the world, metaphorically reconstructed in the interior space of the whare, the realm of Te Ao Mārama (Hone Sadler pers. comm. 2013). In the Te Arawa (tribe of Rotorua) houses located at Whakarewarewa, Wahiao (1908) and Rauru (c. 1900), the metaphor of Tāne propping Ranginui was made more explicit, but in these versions he used his arms not his legs. W.J. Phillipps wrote of the house Wahiao, "The principal pillar supporting the ridge pole has at the top, just under the ridge pole, a representation of the god Tāne Mahuta, he who separated the heaven and the earth, with arms upraised supporting the ridge pole. The carved end of the ridge pole shows Rangi the Sky Parent, with his mouth open ever sorrowing because of this separation from Papa, the earth mother" (Phillipps and McEwen 1946-48: 27). ${ }^{3}$ Tāne makes similar figural appearances on top of 'poutokomanawa 'intermediate posts supporting the ridgepole' in the Whanganui River house known as Poutama (1884) at Galatea (also known as Karatia) (Phillipps 1955: 98-100) and in Hine Nui te Po at Te Whaiti (Mead 1970: Record No. 374048). However, in other versions the poutāhu 'front wall post' is known as Tāne's post (Neich 2011 [1994]: 127).

In the South Island, Teone Taare Tikao narrated a largely Ngāi Tahu version of the creation story in which Tāne propped Ranginui from Papatūānuku with "a great pole" that was later laid horizontally across the sky as with a ridgepole in a whare. From Tane's great pole were suspended the nine layers of heaven (Tikao 2004 [1939]: 29). Tectonically this mirrors the traditional suspension of the kaho 'purlins' on either side of the tāhuhu (Williams 1896: 149).

In these narratives and representations, Tāne is simultaneously the tāhuhu and the tree (the embodiment of Tāne himself as the god of the forest). Ngāti Maniapoto (a western Waikato tribe) historian and genealogist Pei Hirunui Jones wrote of these multiple manifestations, “... when the waka [canoe] Tainui became stuck on the portage between the Waitematā and the Manukau harbours the hauling chant was called. In the chant Tainui, the canoe, is conflated with Taane (God of the Forest)" (in Jones and Biggs 1995: 44). The accompanying footnote records, "The canoe is referred to as Taane, for it was made from a tree which was itself the manifestation of Taane ..." (Jones and Biggs 1995: 44). From the above we can see that the toko and the tähuhu within the whare are foundational to Māori tectonics, and in this built context, they are also foundational to Te Ao Mārama and the life that followed. 
The tribal nature of Māori society often complicates any assertion of the universality of representations such as the above. However, the representativeness of the cosmological and tectonic expressions of Te Ao Mārama and its participants has been well established. Roger Neich (2011 [1994]: 126) wrote of the "... almost universal representation of Rangi the sky-father and Papa the earth-mother shown in cupulo [coupled] on the portion of the ridgepole projecting over the porch, in houses ranging from the earliest chief's house through to Te Hau ki Turanga and all later meeting houses".

Implicated by the omnipresence of Rangi and Papa in the meeting house is Tāne who enacted the narrative of Te Ao Mārama. Tāne's presence within the traditional house is tectonically specific, as discussed above, but Tāne is also more generally associated with both the physical and social dimensions of the house. Neich (2011 [1994]: 127) continues:

... Tanewhakapiripiri is known as the god that presides over the meeting house,
where the qualifier 'whakapiripiri' meaning 'the uniter' refers to the way that
Tane brings people together by enclosing them in the house. Since most of the
materials for the meeting house are obtained from the domain of Tane as the god
of the forest, the house itself is often regarded as the personification of Tane.

It appears from ethnographic records that the chief's house tended to be a wharepuni, 'warm house or sleeping house', carved and typically larger than the other houses in the village (Prickett 1974: 60-62). One of the earliest and most detailed records of these houses was the 1772 account of a house in Spirits Bay by Lieutenant T. Roux of Marion du Fresne's ship Le Mascarin. Of interest to this paper is the reference to "planks two to three inches thick, quite well carved [and] ... a large carved post supporting the ridge of the roof and the two others at the ends" (Olliver and Spencer 1985: 133). Figuration carved into the house suggests the incorporation of identity and whakapapa in the structure. With Neich's comment in mind, it seems plausible that the house is representative of Neich's "near universality" of the presence of Ranginui and Papatūānuku and, by association, the embodiment of the Te Ao Mārama narrative within the whare. Ranginui and Papatūānuku's residence in the pre-contact whare raises the question as to the origin of this tradition and its subsequent extension into the tectonics that supported it.

Pacific cultures have been widely studied in relation to cultural origins and migration history. In this context, as is now known, Pacific architecture is considered tectonically and spatially distinct from Western architecture but strongly related between Pacific Island groups. Professor Mike Austin wrote of the essentials of Pacific building, "structurally these roofs are supported on free-standing posts and the ridge beam is typically supported on poles rather than coupled rafters. The ridge-pole support is, in some ways, the sign of a Pacific building and is given all sorts of importance" (Austin 
2001: 13). Houses of Sāmoa and Tonga (fale), the Cook Islands ('are) and the whare Māori all express this tectonic formula.

The words used for house components also indicate their shared ancestry. The ridgepole is 'au 'au in Sāmoa (Hiroa 1930: 11) but tāhuhu is used on Aitutaki, one of the southern Cook Islands (Hiroa 1927: 15), as in New Zealand. Poutāhu in the whare Māori is poutāhuhu in the southern Cook Islands, and poupou becomes pouturuturu (Hiroa 1927: 4). Polynesian cosmologies, including the Māori Te Ao Mārama construct, are characterised by what ethnologist E.S. Craighill Handy (1927: 34-38) referred to as a "dualistic philosophy" involving parallel oppositions, including light and dark and male and female and tapu 'sacred' and noa 'profane'. While these island cosmologies also shared equivalent narrative events, protagonists and developmental epochs, there are significant differences in their expressions across the different island groups.

Pacific Islands' cultures constructed large gabled buildings, both before and after European contact, in which the genesis of the structure remained the ridgepole and its supporting posts (Treadwell 2015a: 341). The ridgepole was the largest of the building components and necessarily required co-ordinated collective effort to install. The original title of an early 20th-century image (Fig. 3) describes the event of erecting the ridgepole for a Cook Islands ariki 'chief' house as "ceremonial". However, the extent to which the ceremonial nature of this crucial building event was given metaphorical significance through the culture's creation tradition is not yet understood and it is also beyond the scope of this paper to look for the metaphorical extension of these creation narratives into their building culture.

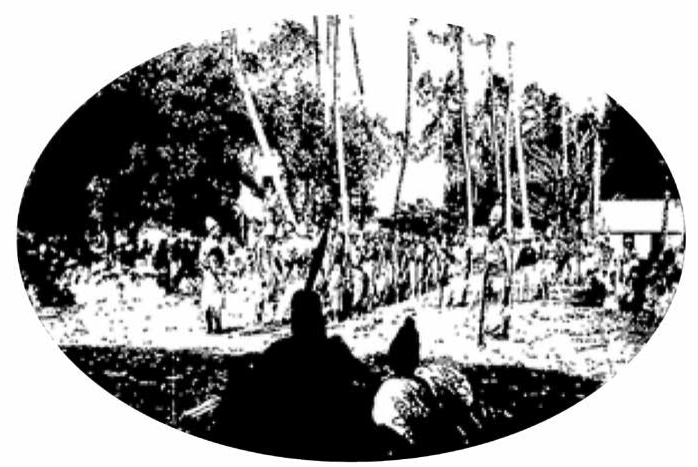

Figure 3. Cook Island Annexation Celebrations. An Important Ceremony Erecting the Ridgepole of the Ariki's House (Otago Witness, 1907) 


\section{THE BURGEONING TĀHUHU AND INVOLVEMENT OF EUROPEAN TECHNOLOGY}

Between settlement and the 19th century, the whare Māori expanded from small domestic buildings to large religious and political meeting houses. The increased width of these large houses was taken up by elongation of the rafters on both sides of the tāhuhu - each side assuming half of the increase in the building's width. As houses increased in length from between 5-6 $\mathrm{m}$ to over $25 \mathrm{~m}$, the length of the single ridge-beam was increased to match. This single element of the building was increased by up to five times its pre-19th century length. With few exceptions, the tāhuhu of the large churches and whare buildings of the 19th century were cut out of single trees. ${ }^{4}$

Sundt (2010: 114-18) has argued that it was the construction of the large whare karakia 'churches' between the 1830s and 1860s, made possible because of Māori uptake of European technology, which enabled Māori to construct the larger whare following the New Zealand Wars. However, there is now increasing evidence that Māori were building very large whare as early as 1820 , suggesting that the church building occurred in the context of a building culture that was, in some regions, already familiar with the problems of large-scale construction. In a summary of evidence of early large-scale whare structures archaeologists Robert Brassey and Matthew Campbell (2016) documented a house site at the Te Pua a te Mārama Village visited by Samuel Marsden in 1820. The village was identified in local tradition as that of the Ngāti Whātua leader Mawete and was located $7 \mathrm{~km}$ to the west of Helensville. ${ }^{5}$ The site has been interpreted as indicating a house $30 \mathrm{~m}$ long by $15 \mathrm{~m}$ wide. This is wider than any of the whare karakia described by Sundt (2010).

Much of the discourse surrounding the development of whare karakia and the large meeting houses that followed has focused on the Māori adoption of Western industrial technologies, such as block and tackle, mill-sawn timber, and mortise and tenon connections. It appears, however, that the scale and the geometries of the late 19th-century tăhuhu and heke would have almost precluded their production using Western technology.

The tähuhu of the 19th-century whare was sectionally formed as an isosceles triangle with the two inclined faces at around 38 degrees from the horizontal. To cut these faces at a sawmill would have required a demanding series of manipulations of the large baulk of timber and the capability of the saw to cut at selected angles. First, the raw log would need to have been partially squared with at least three passes through the saw. Then it would have required that the blade of the saw be set to approximately 52 degrees. Assuming that the saw, at this time and context, had this unlikely capability, then the massive beam would have to have been rotated end-for-end between each of the angled cuts. 
If the mill had, as is much more likely, a fixed vertical blade, then the required angle of cut could potentially have been achieved if the baulk of timber was set up on a jig. The jig or supporting frame would have had to position the developing tāhuhu at the correct angle for its whole length (up to $25 \mathrm{~m}$ ) as it passed through the saw. This would need to have been repeated to cut the other face of the beam after rotating the beam and the jig, end-for-end. ${ }^{6}$

Additionally, the bed of the saw would have needed to be able to support and guide the great length of timber through the blade. None of these requirements would have been easily or likely met in a 19th-century rural mill focusing on the production of significantly shorter lengths of rectangular section timber. So, while the process was potentially achievable, it would have been both technically and physically difficult, and very time-consuming to set up and implement. Even greater difficulties arise when contemplating the production of the semi-circular section curved heke using Western industrial technology.

This analysis is supported by a more recent account that the replacement 22 m tāhuhu for a re-building of Tāne Whirinaki (Ngāti Ira meeting house built near Ōpōtiki in 1874) was adzed (not milled) by Paki Withers at Waioeka out of a raw totara (podocarp species) log around 1940 (Waka Huia 2014). All this suggests that in the last three decades of the 19th century it would have been extremely unlikely that Māori would have found greater efficiencies in the production of these key elements of the whare using Western technology. Further, even by the mid-20th century, European industrial technology would struggle to practicably produce these primary components required in the traditional whare.

\section{SECURING THE TĀHUHU}

The tāhuhu of the large, late 19th-century whare structures like Mataatua built at Whakatāne in 1874 (Mead 1990: 18), Hotunui at Parawai in 1878 (Barton and Reynolds 1985: 5) and Te Whai a te Motu at Ruatahuna in 1888 (Cowan 1930: 127), are calculated to have weighed around $1000 \mathrm{~kg}$. With the emplacement of such heavy components, the on-going structural stability of these buildings became contingent on the security and immobility of the tāhuhu in its location on top of its supporting posts. However, there is little certainty in the literature of whare construction about how tăhuhu were secured to the top of their supporting pou. Hiroa (1949: 123) wrote: "The flat base surface [of the tāhuhu] sometimes two feet wide rested on the ridgepost and was fixed in position by wooden pegs driven from each side into the tops of the ridge posts or sometimes lashed to eyes". Hiroa draws this directly from the Rev. Herbert W. Williams' 1896 (p. 147) translated account of the Ngāti Porou carver Rev. Mohi Turei. However, Ngāti Porou scholar Apirana Ngata's subsequent commentary on the Williams paper implied that Mohi 
Turei, although respected and well informed on Ngāti Porou tikanga 'lore, practices', was not known as an authority on Ngāti Porou house construction (Ngata 1897: 85). Ngata used his father's traditional knowledge to clarify aspects of Ngāti Porou building processes. On this basis the description, reproduced by Hiroa, must be seen as indicative only of Ngāti Porou practice. The methods of other tribes remain unclear. In 1896, Augustus Hamilton included identical information in his publication but in addition he illustrated wooden pegs in the cross-sectional drawing of the whare (Hamilton 1896: 82). However, these drawings must be seen as entirely interpretive because the drawings in the original Williams paper do not show pegs.

As a part of his 1924 discussion of Māori construction, Elsdon Best (1924: 195) described the raising up of the tāhuhu: "When the ridgepole was swung up to the crosspieces [of the rangitapu] it was, of course, higher than the top of the posts that were to support it, and could then be lowered so as to rest on them" (author's emphasis). However, it is not clear how to interpret this as subsequently, when discussing the structure of the whare, Best (p. 563) referred to the securing of the tâhuhu to its supporting posts, "by strong ties of $a k a$ or vines".

Sundt (2010) interrogated the structural remains of Rangiātea, the Ōtaki whare karakia, through forensic site-drawings by architect Chris Cochran following the 1995 fire that destroyed the church. Sundt pointed to the presence of mortise and tenon joints (Fig. 4) connecting the tāhuhu to the poutāhu 'supporting post in the front wall', and the poutokomanawa 'mid-span supporting post' as "... coinciding with Māori adoption of the Western method of block and tackle for hoisting massive timbers" (Sundt 2010: 118). Sundt's analysis of the construction of Rangiatea is susceptible to different interpretations.

Rangiātea was built by Raukawa iwi and affiliated $i w i$ Te Wehiwehi (of the lower West Coast of the North Island) beginning in 1848 with overseeing involvement of the mission in the person of the Rev. Samuel Williams (S. Treadwell 1995: 78). The stealthy nocturnal shortening of the tāhuhu by Rev. Williams, against the wishes of the Māori builders, indicates that he was determined to exert significant influence over the construction of the building (S. Treadwell 1995: 41). The amputation of the tāhuhu was significant in that the loss of the ten feet [c. $3 \mathrm{~m}$ ] of length precluded construction of the mahau 'porch' and the formal and ritual use of the building as a whare. The shortening of the tähuhu also could be seen as the "denial of an embodying ancestor" (S. Treadwell 1995: 42). Williams' interventions into the building process at this primary level must cast some doubt on the use of mortise and tenons to secure the tāhuhu as a Māori initiative at this time. 


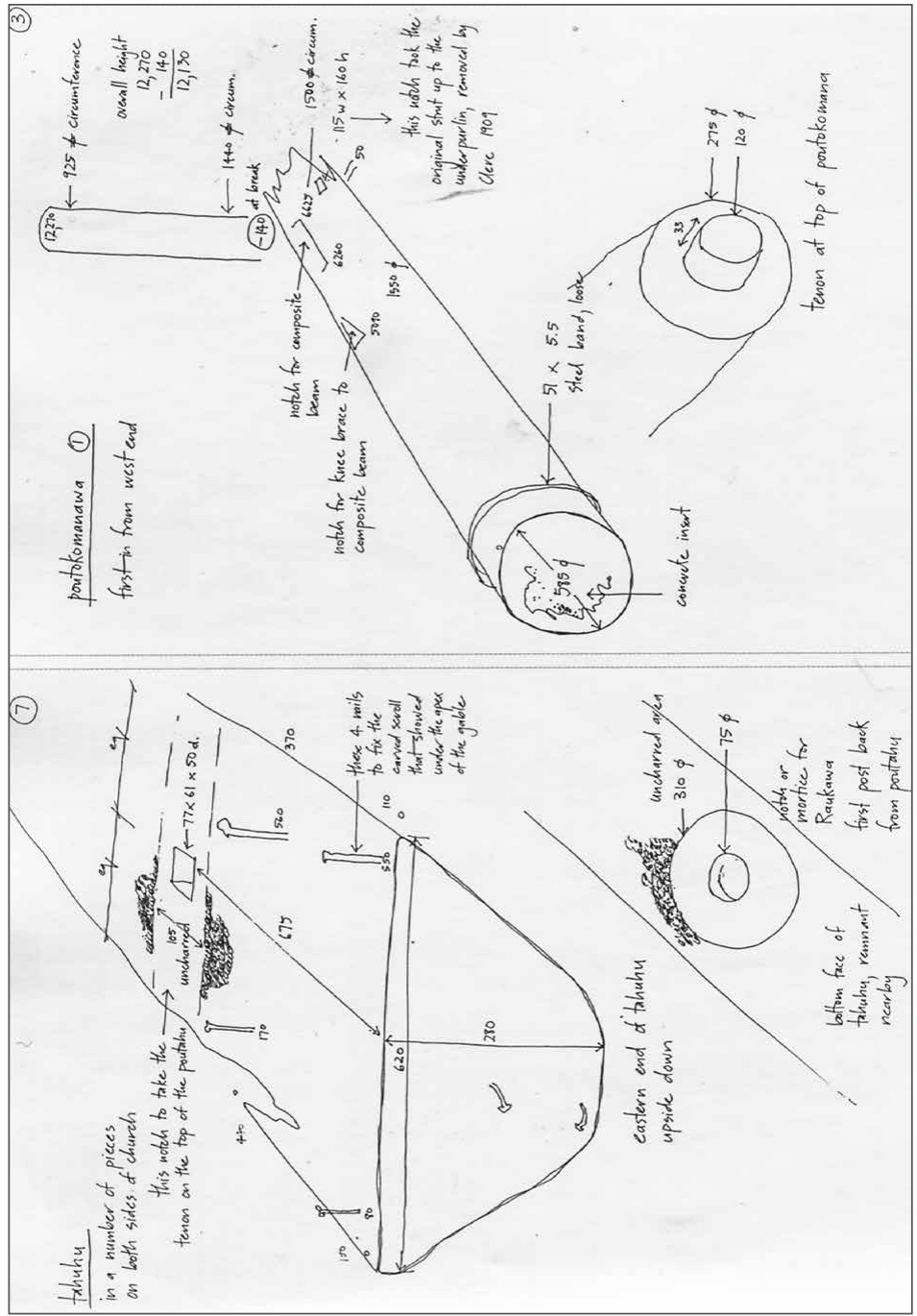


It has been suggested above that Sundt's proposition that Māori technology would struggle to raise the tăhuhu represented a misunderstanding of both the process and its capability (Treadwell 2012: 1161). Similarly, the use of Western mortise and tenons to secure the tāhuhu at Rangiātea appears not to represent an advance in Māori construction, but rather a misplaced Western intervention in Māori constructional tradition. Coordinating five tenons to engage with up to five mortises on top of five separate $12 \mathrm{~m}$ posts requires an extremely high level of constructional accuracy and positional control of the tăhuhu suspended high above the ground and controlled with ropes and props from below. That the Māori builders achieved this is more a testimony to their building skills than to the appropriateness of the use of multiple tenons and mortises to locate the tāhuhu on its posts. The Rev. Hohepa Taepa of the Rangiātea Vestry related an account of the original construction process, which illustrates the difficulty and the anxiety this process can cause: "There was another incident concerning the ridge pole. The builders were finding great difficulty in dropping the ridgepole into position on the centre pillars when there was a sudden outburst from the people. The pole had fallen into place and the Māori folk broke into a haka 'dance' of joy and gladness" (Taepa 1966: 36).

Cutting multiple tenons to fit corresponding mortises is exacting work in normal manual carpentry as even minor discrepancies multiply, creating, this quote suggests, difficulties in assembly. This quote is consistent with a description of a prolonged struggle to get all the tenons on top of the separate poupou to simultaneously engage with the mortises cut into the underside of the tāhuhu. Perhaps as a consequence of the difficulties experienced at Rangiatea, mortise and tenon construction was not, as will be shown, to become characteristic of the large-scale Māori constructions of the late 19th century.

The almost $25 \mathrm{~m} t \bar{a} h u h u$ of the much-travelled Mataatua wharenui is now in storage in Whakatāne in three lengths, its segmentation a matter of shipping convenience (Mead 1990: 83). An examination of the three lengths shows that there are no mortises to locate any tenons on the top of the supporting poupou. The carvers who reconstructed Mataatua in 2011 confirmed that the original tăhuhu (not included in the recent reconstruction of the house) had been kept in place on top of its posts by its own weight (Jeremy Gardiner pers. comm. 2011).

Of additional relevance here is the concave, adzed under-surface of the Mataatua $t \bar{a} h u h u$ (Fig. 5). Its profile coincides with the curved convexity of the poutuarongo 'end wall post' and poutāhu (Fig. 6). There is a reference to this feature in Best's discussion of whare construction (Best 1924: 563). As a means of locating and securing the tāhuhu it seems that the reciprocal curving of posts and beams confers some constructional advantages. For example, 


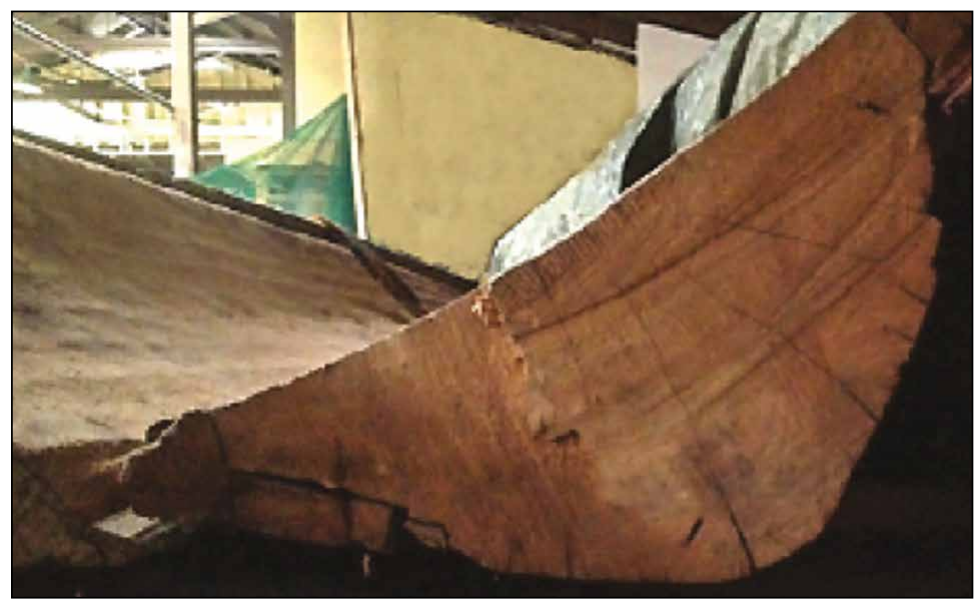

Figure 5. Curved under-surface of the tāhuhu of Whare Mataatua, Whakatane. Photo by J. Treadwell (2013); used with permission of Ngāti Awa.

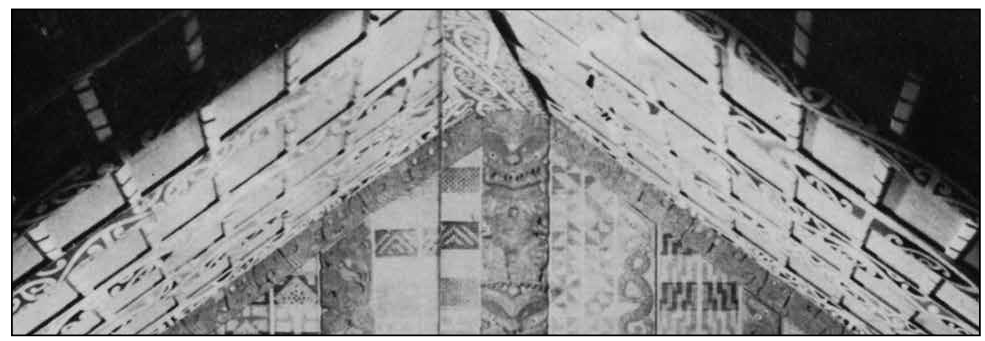

Figure 6. Interior of Whare Mataatua: The concavity of the tāhuhu corresponds with convexity of poutuarongo. Detail from Phillipps and Wadmore (1956: 18).

the curved tops of the supporting posts allowed the tâhuhu to be adjusted (rotated in axis) to a central position on top of the poupou. In addition, the central (neutral) positioning of the tāhuhu assisted its stability through both the slightly increased frictional area of the curved surface (compared to a flat surface) and its inherent resistance to lateral displacement. This technique can be seen as a more practical alternative to the difficulties of aligning multiple tenons with multiple mortises, as experienced by the builders of Rangiātea. 
On loan to the Auckland War Memorial Museum by it owners Ngāti Maru, the meeting house Hotunui, was constructed by Ngāti Awa carvers in 1878 . In this case, the $24 \mathrm{~m} t \bar{a} h u h u$ has, in its decades in the museum environment, twisted at the rear of the house, exposing the top of the poutuarongo. Like its equivalent in Whakatane wharenui, Mataatua, the tāhuhu has no mortise and tenon to secure it and it remains at the top of the post under its own weight. Neither is there any evidence of a tenon locating the poutokomanawa to the underside of the tāhuhu.

There are two other complete tāhuhu, known to be in New Zealand museums. In Te Papa Tongarewa Museum of New Zealand resides the complete carved and painted tāhuhu from the Ngāti Raukawa whare Tokopikowhakahau, originally constructed near Tīrau around 1885 (Phillipps and McEwen 1946-48: 43) (Fig. 7). Like the Mataatua tāhuhu, but smaller at $15 \mathrm{~m}$ in length, this tâhuhu lacks any mortise openings on the underside and there is no evidence of pegs or holes in the sides. The tähuhu of a wharepuni from Te Miro at Maungakawa, now held at the Waikato Museum, also lacks evidence of any fixings apart from what appears to have been an end coupling to another tähuhu in an adjacent wharepuni. However, a tenon was used on the lengthened poutuarongo of Tāne Whirinaki c.1940 and the poutokomanawa of the whare known as Whakauetaunga at Awahou c.1883. ${ }^{7}$

At this distance in space and time it is not known why Māori adopted aspects of Western technology in some situations and not in others. While pragmatic and technical explanations are the most accessible and convenient, it may be that there are also more complex issues at work that reflect the intersection of Western and Māori world views. It is clear in Sundt's (2010: 123) accounts that the mission-influenced shift from whare rununga assembly houses' to whare karakia involved complex negotiations between world-views expressed in building form, carved representation and indeed technology. It is possible that in the course of these negotiations technical changes, such as use of mortise and tenons, were acceptable to Māori because, in the mission context, structure and cosmology could be more easily separated. What does seem clear is that not all Western techniques were seen as acceptable or technically adequate in subsequent large-scale whare constructions.

There are several large, late 19th-century whare in Aoteoroa that survive as evidence that Māori recognised that the elevation of the tāhuhu, which had required the collective effort of people, along with the mediation of the tohunga and the authority of the atua, did not also require the discipline of the Pākehā mortise and tenon to keep it in place. Perhaps Māori calculated the sheer mass and scale of the tâhuhu to be commensurate with both the collective effort to produce and position it, and the cosmological negotiation that sanctioned it. Given the examples above it seems that the tenons and 
Figure 7. Tāhuhu from Whare Tokopikowhakahau. Te Papa Tongarewa Museum of New Zealand, 2014. Used with permission of Jonathan Tai, Raukawa (Waikato). 
mortises as used in Rangiātea in 1848 were not seen by all $i w i$ as a necessary feature of large-scale whare construction. The final issue overlaying this discussion of the security of the tāhuhu in place on top of its supporting posts, is consideration of the effects of post-tensioning and the role of the tauwhenua in maintaining the position of the tăhuhu. This will be discussed below as part of the detailed implementation of post-tensioning.

While hap $\bar{u}$ and $i w i$-led church-building programmes such as the one for Rangiātea, had provided Māori with more opportunities to extend their largescale building practices, their duration was relatively short-lived because, in particular regions, many Māori turned away from the church missions and adopted syncretic forms of religion, such as Ringatū movement. Under Te Kooti's influence, Māori of the central North Island, Bay of Plenty and Poverty Bay areas in particular, built their churches in whare form, extending whare traditions such as carving but also innovating with the development of figurative painting (Linzey 1990: 26-32). For example, Tāne Whirinaki was originally built as a whare rūnanga 'council house' in resistance to the land confiscations of 1865 , but following its rebuilding and enlargement in 1886 its kaupapa 'purpose' shifted and its role at Waioeka became that of a whare karakia (Treadwell 2015b: 31).

Many of the meeting houses/whare karakia built from 1870s onwards approached the scale of the earlier churches but these whare were structurally innovative in ways that were consistent with Māori technical traditions. Examples of these solutions included the development of pre-cambered and semi-circular section heke. With the additional application of cross-sectional post-tensioning to the house, these developments increased the spanning capacity of heke, and with it the width of the whare.

\section{THE TĀHUHU IN STRUCTURE}

The collapse of masonry pediments and gable-ends following the Christchurch earthquakes in 2010 and 2011 confirm a general principle of Western engineering: that weight in buildings is best kept low to the ground. This is to reduce the demands on vertical support, but is also to avoid the effects of inertia should horizontal forces come to act on the structure. Given the perils and difficulties associated with the production and elevation of the tāhuhu, why did Māori choose to build their houses with such apparently inordinate components? Was the massive triangular section of the tāhuhu foremost a response to the supernatural world, a balancing out of cosmological and physical forces? And what does the theory of physics have to say about the structural performance of beams like this?

When compared to rectangular section beams, the triangular section tāhuhu has much more cross-sectional mass. The fragments of the original Tāne Whirinaki tāhuhu indicate a beam $600 \mathrm{~mm}$ across the base with 38 degree 
sides and a height of $357 \mathrm{~mm}$. A rectangular-section beam of equivalent vertical load capacity is much less massive: $325 \mathrm{~mm}$ by $90 \mathrm{~mm}$ (John Chapman pers. comm. 2015). If the rectangular beam is a closely calculated equation between beam performance and minimum materials, then the triangular section tāhuhu appears to have been furnished by other priorities.

While a relatively thin beam of $325 \mathrm{~mm}$ by $90 \mathrm{~mm}$ might perform comparably to the triangular tāhuhu of Tāne Whirinaki in terms of vertical loads, in relation to construction processes the thinner beam has some disadvantages. First, it is more likely to deflect laterally under horizontal rafter pressure. Second, as a rectangular-section ridgepole presents a small surface area on the top face, it is harder to securely attach the heke to. Alternatively, the heke must be face-fixed to the ridgepole. However, neither alternative had the security in place, or the ease of fixing, of the heke, which was rebated against the bottom edge and fixed to the inclined upper surfaces of the triangular $t \bar{a} h u h u$.

Given the extreme physical difficulties in procuring and elevating such a large triangular section beam, it seems unlikely that the constructional advantages of the triangular-section beam are sufficient to explain its persistence throughout the 19th century. However, the commitment to the great mass and scale of the triangular-section tāhuhu is more reasonable when considered in relation to the Māori technology uncovered at Kohika that is, post-tensioning.

\section{PRE-CAMBERING AND POST-TENSIONING}

At Kohika, the archaeological evidence showed that the tauwhenua had been pulled tight over the tâhuhu from both sides of the whare, and down the back of each opposing heke, before being lashed to the back of the corresponding poupou. By the mid-19th century, in many whare, the contacting junctions between the heke and the poupou, and between the heke and the tāhuhu, had been specifically fabricated to lock together under tension (Fig. 8.). At the upper end of the underside of these heke a rebate was formed to engage with a squared shoulder on the bottom edge of the tähuhu (Hiroa 1949: 126). In the first half of the 19th century the heke, of rectangular section, engaged with a rectangular slot in the роирои and were locked in place with compression shoulders formed on both components. Both the top and bottom joints of the heke worked in compression, and the stability of the joints required that a constant compressive pressure be maintained along the axis of each element.

By the late 19th century, these joints had become more sophisticated in order to cope with the increased sizes and forces of the expanding whare, and to transmit the increased loads more directly between components. In response to the development of semi-circular sectioned heke, the junction between the poupou and the bottom end of the heke had been transformed 


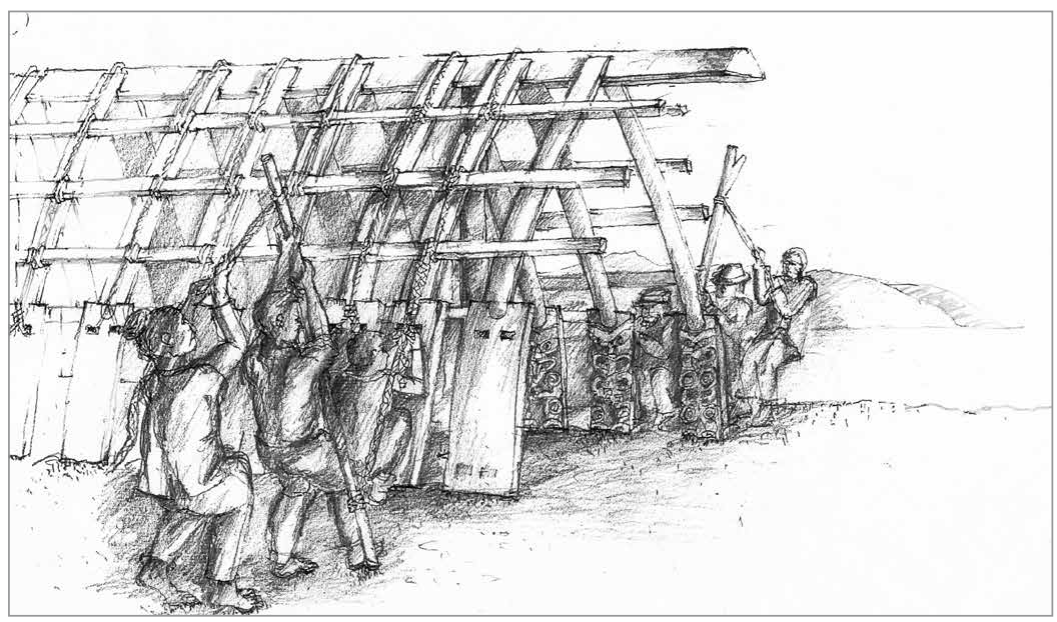

Figure 8. Interpretation of post-tensioning process, incorporating evidence from whare components, historic accounts and structural model testing. Kaho paetara 'horizontal batten at top of poupou' omitted on near side for clarity. Drawing by J. Treadwell, 2016.

into what was known as the rua whetu joint, which was a sophisticated semicircular socket-joint that frequently worked with a compression shoulder (Fig. 9). The rua whetu joint is not apparent in early 19th-century sketchbooks and diaries, but is referred to in ethnological accounts from the mid-century (Taylor 1855: 387). The earliest surviving components of a rua whetu joint have been identified in poupou and heke from Māui Tikitiki-a-Taranga, built at Paerauta in 1865. The poupou are in the Auckland War Memorial Museum and some of the heke are at the Tairāwhiti Museum. The rua whetu joint was most widely used across the Bay of Plenty and down the East Coast.

In the second half of the 19th century, two innovations combined to improve the functionality of the locked frame system, in part by a more direct engagement with the mass of the tāhuhu. The first was the pre-cambering of the heke. Pre-cambering is the shallow convex curvature built into a beam to compensate for deflection under load. While pre-cambering does not confer greater load-carrying capacity on its own, when combined with post-tensioning it does. It appears that in the application of post-tensioning, in Ngāti Porou practice, the tauwhenua was separated from the top surface of the heke, by increasing the thickness of the centre kaho (Ngata 1897: 87). The effect of this, when the tensioning was applied, was to slightly flatten the pre-camber of the heke, an effect that marginally increased its 
length and, when constrained by the mass of tähuhu against which it bore, increased the compressive force at the junctions.

These effects were demonstrated and documented in a large-scale structural model built by the author at the University of Auckland in 2015. While the details of this modelling project will be discussed in detail in a future publication, three generalities can be drawn from it. The first is that the operational method of post-tensioning combines tension and compression to achieve stability of the whare structure. This is also characteristic of traditional and contemporary maritime construction. (For example see: http:// smalltridesign.com/masts/Rigging-Mast-Loads.html). Not only does tensioninduced compression form the basis of rigging systems but it is widely used to join strakes onto dugout canoe bodies, floats to outriggers and cross struts to hulls and is a ubiquitous form of construction in the Pacific.

The second general point is that the tauwhenua augmented the weight of the tâhuhu in resisting uplift under constructional tensioning, as it did in response to uplift generated by wind. At the same time the tauwhenua was resisting uplift, it was also acting as an additional restraint against any movement of the tāhuhu from its position on top of its posts. This may explain in part the Māori decision not to use mortise and tenon connections between the tāhuhu and its supporting posts in many late 19th-century whare. The third understanding to emerge from the structural model was that it is beneficial in post-tensioned buildings to have the apex of the tăhuhu rounded to a gentle radius. This rounding of the apex eased the movement of the tauwhenua over the top of the tāhuhu (Fig. 9). This feature is characteristic of all the tāhuhu examined to date.

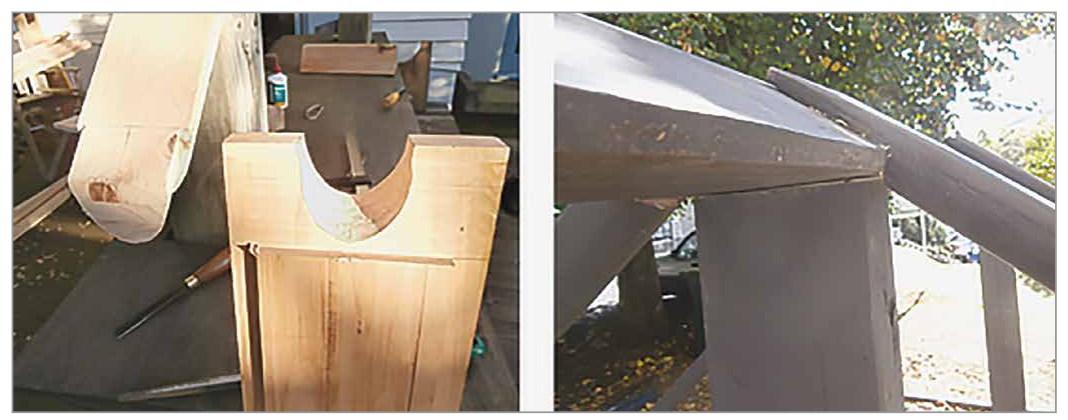

Figure 9. Heke/tāhuhu junction (left) and rua whetu joint (right) fabricated as part of a structural model designed, built and photographed by the author in 2015 to investigate the tectonic effects of post-tensioning. Note compression shoulders on both ends of heke. 
The crucial issue for this paper is that the amount of tension-induced compression applied to "lock" together the structural frames of heke and poupou on both sides of the tāhuhu was ultimately limited or controlled by the weight of the tāhuhu. As engineer, Regan Potangaroa (pers. comm. 2013) commented, "The weight of the main beam [tāhuhu] would have been important as the degree of post-stressing could only be equivalent to the weight of the structure reacting against it, the so-called dead load."

The weight of the tăhuhu, the very thing that had agitated European commentators into print (Treadwell 2012), plus the pre-camber of the heke, became the means by which compression could be increased in the joints across the house. Increased compression in the joints and their great shear strength meant that the whole structural section would, in addition, become implicitly resistant to uplift. University of Auckland engineer John Chapman (pers. comm. 2014) emphasised that uplift from wind would have been the biggest temporary load on the house, creating a tensile load on the roof elements. The tensioned tauwhenua and the compression effect of the great weight of the tăhuhu countered this effect and was described by Chapman as "a very elegant solution to the problem of uplift".

It is necessary to reposition this discussion again, away from the preceding Western structural analysis, to a way of thinking that is materially grounded but informed by matauranga Māori. In this conception, the tāhuhu is a mass suspended, a carefully reconciled formation of present structure and past ancestry. In the construction of the house, as scripted by Te Ao Marrama, the social and metaphysical space of the house is forced open. The poutokomanawa, poutāhu and poutuarongo take up the weight of the tāhuhu (now conflated with Tāne). On each side of the whare, the people strain the heke and poupou upwards against the tähuhu. The interior world of the whare is manifested between the massive inertias of Tāne and Papatūānuku. In this reading of the structural and cosmological house, it is the mass of Tāne, simultaneously atua and ancestor, who constructs and maintains present social space, not as elsewhere in the Pacific in a lashed metaphor of social cohesion (Dixon 2015: 410) but as a light-filled opening given form and forced from the darkness of Te Pō.

In this primordial context, the construction and inhabitation of the interior of the whare may be seen as somewhat perilous occupations enabled by the scaffolding of ritual and respect. The construction of wharenui in the late 19th century was still controlled by complex protocols directed at the maintenance of the mana 'prestige, power' of the emergent house, its carvers, the ancestors and atua represented. The significant physical perils of construction were matched by the dangers of tapu associated with the process. Transgression of the protocols designed to preserve mana sometimes led to the deaths of people 
linked to the house and the collapse of built structure. Tāne Whirinaki acquired layers of tapu associated with prophets Te Kooti, and later Rua Kenana. Attempts to reconstruct the house failed catastrophically on two occasions, with a carver dying and the tāhuhu being thrown aside. After the second failure the fallen $t \bar{a} h u h u$ was considered irreconcilably dangerous and was burnt on the marae while the poupou were placed in storage (Treadwell 2015b: 35). Another example is Nuku te Apiapi, a Te Arawa house. Here the construction was traumatically set back by the breaking of a tapu 'restriction' attached to the practices of one of the master carvers, which was followed by the death of several relatives associated with the project (Neich 2008 [2001]:154-55).

Occupation of the house traditionally proceeded only after complex rituals to render the house safe for women to enter. Mereana Mokomoko recounted one ceremony and the structural consequence of failure to observe it: "... three women (myself, Kitemate Kiritahanga and Mere Taipari) were sent for to takahi te paepae (to tread on or cross over the threshold, and thus remove the enchantment which debars women from entering a sacred house until this ceremony is ended), for, as you know, the ridge-pole would sag down in the middle and destroy the appearance of the house were this ceremony disregarded" (Mokomoko 1897: 42).

In this complex narrative, the influence of the tapu of the house seems to be extended beyond people to potentially affect the security of the ancestral relationships as enacted in the house's structure. If the tähuhu sagged, not only would that disturb the structural relationships below it, but the deformation would possibly have been seen as damaging to the mana of the tüpuna 'ancestors' and distorting to the relationships that are embodied in the carved and painted structure. When rendered noa by the enactment of this ceremony the completed house remained an active assembly of physical and social gradients, oppositions and prohibitions that proscribed its use. This formation was given orientation and significance by the physical scale and deep logic of the house's structure and associated mana.

$* * *$

This paper has argued a close correspondence between the tāhuhu as a primal cosmological figure in a cultural narrative about origins, and as a fundamental tectonic element within the structure of the 19th-century whare Māori. The tăhuhu has been represented in the text as simultaneously monumental in ancestry and scale. Referencing the past within the social space of the whare, the tāhuhu maintains the present and points to the future.

Tāne's mass is also of course the measure of the collective effort that must go into his elevation. This commitment enforces the bodily knowledge of the 
forces at stake in the construction of a whare but also insists on the collective participation of hapu or $i w i$, which establishes the house and maintains the social world that it structures.

Colonial and subsequent Western discourse has had little to say about the tāhuhu other than to remark on its size and insist that it required Western technology to position it. This paper has proposed that the tāhuhu was also a key element within a sophisticated and high-performing Pacific building technology that is, in many ways, antithetical to Western building principles. Further, as part of that proposal, arguments have been presented that it was the elevated mass of the tāhuhu that sustained the post-tensioning process.

As a post-script to this paper, and specifically the argument for the existence of a sophisticated Māori building technology, there is also historical evidence of its structural resilience. In a survey of the newspapers available on the National Library of New Zealand 'Papers Past' website (https://paperspast. natlib.govt.nz/), between 1840 and 1940, there was only one mention found of a Māori meeting house being blown down (New Zealand Herald 1934). While it was regularly recorded during the period surveyed that Māori houses were destroyed by fire (although no mention is made of the many houses torched by colonial and Imperial troops), no record was found of wharenui being destroyed by earthquakes or volcanic eruptions. It was, in fact, during the most extreme seismic and volcanic event of the 1840 to 1940 period that Māori whare construction most vividly demonstrated its resilience. During the ash showers and earthquakes of the Mt Tarwera eruption, when the MacCrae Hotel had largely collapsed, local Pākehā and Māori sought refuge in the Guide Sophia's whare and the Hinemihi wharepuni, both of which survived the eruption intact (New Zealand Herald 1931).

\section{NOTES}

1. In this discussion the interior of whare constitutes Te Ao Mārama the world of light /enlightenment. Outside the whare, within the marae, is Te Pō (darkness, night) and beyond the marae is Te Korekore, the realm of potential.

2. The Rev. Herbert Williams' 1896 account of the construction of the whare indicates that following the placement of the central posts the tāhuhu was the first element to be fixed in place. All subsequent structural elements were fitted below it, in genealogical and structural relationship to it.

3. Wahiao was opened in 1908, built after the famous Whakarewarewa house known as Rauru had been sold.

4. Totara (Podocarpus totara), Kahikatea (Podocarpus dacrydioides) and Kauri (Agathis australis) trees all grew in excess of $30 \mathrm{~m}$ high. These species were typically used to form the single tāhuhu of late 19th-century whare. Where houses exceeded this general length they may have required the tâhuhu to be formed from two elements (Sundt 2010: 125). 
5. The Te Pua a te Mārama Village site is now listed as a Category A site in the Auckland Unitary Plan (Brassey and Campbell 2016).

6. This process was modelled at a small-scale using a table saw with the blade at right angles to the table surface. With fixed saw blades the construction of robust angled jigs to support the timber is the only way of cutting at the angles necessary. The necessity to rotate the timber end-for-end is a consequence of this.

7. Tāne Whirinaki, a large Whakatohea house, was rebuilt for Te Kooti at Waioeka in 1886, apparently with tenons on top of the pouturarongo, poutokomanwa and poutāhu with which to engage the tāhuhu. Complicating the issue, it turns out that the house has been reconstructed several times, including during 1946. It was at this time that all the vertical supports were increased in length. It is not known if this included the tops of posts supporting the tāhuhu. If so, this may have involved adopting mortise and tenons.

\section{REFERENCES}

Austin, Mike, 2001. Pacific Island architecture. Fabrications Journal of the Society of Architectural Historians, Australia and New Zealand 11 (2): 13-19.

Barton, Gerry and David Reynolds, 1985. Hotunui, The Restoration of a Meeting House. Auckland: Auckland Museum.

Best, Elsdon, 1924. The Māori as He Was: A Brief Account of Māori Life as it was in Pre- European Days. Wellington: Government Printer. 2005 [1927]. The Pa Māori. Dominion Museum Bulletin No 6. Wellington.

Brassey, Robert and Matthew Campbell, 2016. Schedule of Significant Historic Heritage Places, Auckland Unitary Plan. Auckland: Auckland Council.

Brown, Deidre, 2003. Tai Tokerau Whakairo Rākau: Northland Māori Wood Carving. Auckland: Reed Publishing.

Bruzina, Ronald and Bruce W. Wilshire, 1982. Phenomenology, Dialogues and Bridges. Albany: State University of New York Press.

Chapman, John, pers. comm. 2014 and 2015.

Cowan, James, 1930. The Maori, Yesterday and To-day. Auckland: Whitcombe and Tombs.

Dixon, Rod, 2015. Ties that bind. In R. Dixon, L. Crowl and M. Tuainekore Crocombe (eds), Cook Islands Art and Architecture. [Suva], Fiji: University of the South Pacific Press, pp. 400-17.

Ellis, Ngarino, 2016. A Whakapapa of Tradition: 100 Years of Ngāti Porou Carving 1830-1930. Auckland: Auckland University Press.

Gardiner, Jeremy, pers. comm. 2011.

Hamilton, Augustus, 1896. The Art Workmanship of the Maori Race in New Zealand: A Series of illustrations from specially taken photographs with descriptive notes and essays on the canoes, habitations, weapons ornaments and dress of the Maoris, Together with lists of words in the Maori Language used in relation to the subjects. Wellington: New Zealand Institute.

Handy, E.S. Craighill, 1927. Polynesian Religion. Bernice P. Bishop Museum Bulletin 34. Honolulu. 
Hiroa, Te Rangi [Sir Peter Buck], 1927. The Material Culture of the Cook Islands (Aitutaki). New Plymouth: Thomas Avery \& Sons.

1930. Samoan Material Culture. Bernice P. Bishop Museum Bulletin 75. Honolulu. 1949. The Coming of the Maori. Wellington: Maori Purposes Fund Board.

Ingold, Tim, 2011. The Perception of the Environment: Essays on Livelihood, Dwelling and Skill. London: Routledge.

Irwin, Geoffrey, Rod Wallace and Roger Neich, 2004. Houses, pataka and woodcarving at Kohika. In G. Irwin (ed.), Kohika: The Archaeology of a Late Māori Lake Village in the Ngāti Awa Rohe, Bay of Plenty, New Zealand. Auckland: Auckland University Press, pp. 122-49.

Jones Pei Hurunui and Bruce Biggs, 1995. 'Ngā Iwi o Tainui, 'The Traditional History of the Tainui People. Auckland: Auckland University Press.

Leach, Foss, Janet Davidson and Rod Wallace, 2000.The form and construction of the Makotukutuku House, pre-European dwelling in Palliser Bay, New Zealand. New Zealand Journal of Archaeology 21 [1999]: 87-119.

Linzey, Mike, 1990. The tapu tradition of Ringatu houses. New Zealand Historic Places 29: 26-32.

Makereti, 1986 [1938]. The Old-Time Maori. Auckland: New Women's Press.

Mead, Sydney M., 1970. Hine nui te po, Poutokomanawa Te Whaiti. Record No: 374048, Anthropology Photographic Archive, University of Auckland, Auckland.

1990. Nga karoretanga o Mataatua Whare, The Wanderings of the House Mataatua. Whakatane: Te Runanga o Ngati Awa.

Mokomoko, Mereana, 1897. The building of Hotunui, Whare Whakairo, W.H. Taipari's carved house Thames, 1878. Transactions and Proceedings of the New Zealand Institute 30: 41-44.

Neich, Roger, 2008 [2001]. Carved Histories: Rotorua Ngati Tarawhai Woodcarving. Auckland: Auckland University Press.

_2011 [1994]. Painted Histories: Early Māori Figurative Painting. Auckland: Auckland University Press.

Ngata, Apirana T., 1897. Notes on the Rev. H.W. William s' paper on 'The Māori Whare'. Journal of the Polynesian Society 6: 85-88.

New Zealand Herald, 1931. Tarawera Eruption. Vol. LXVIII, Issue 20895, 10 June, p. 12. Available at: https://paperspast.natlib.govt.nz/

New Zealand Herald, 1934. Trail of Damage, Whirlwind in North. Vol. LXXI, Issue 21859, 23 July, p. 8. Available at: https://paperspast.natlib.govt.nz/

Olliver, Isabel and Jeremy Spencer, 1985. Early Eyewitness Accounts of Māori Life: Extracts from the Journals of the ships Mascarin and Marquis de Castries, 1772. Wellington: ATL Endowment Trust.

Otago Witness, 1907. Cook Island Annexation Celebrations. An Important Ceremony Erecting the Ridgepole of the Ariki's House. Issue 2787, 14 August, p. 49. Available at: Papers Past, National Library of New Zealand (https://paperspast. natlib.govt.nz/)

Phillipps, William J., 1946. Māori Art. Wellington: Harry H. Tombs.

1955. Carved Māori Houses of Western and Northern Areas of New Zealand. Wellington: Government Printer. 
Phillipps, William J., and J.M. McEwen, 1946-48. Carved Houses of Te Arawa. Dominion Museum Records Ethnology, Vol. 1, No. 2. Wellington.

Phillipps, William J., and Dr J.C. Wadmore, 1956. The Great Carved House Mataatua of Whakatane. Wellington: The Polynesian Society.

Potangeroa, Regan, pers. comm. 2013.

Prickett, Nigel, 1974. Houses and House Life in Prehistoric New Zealand. Unpublished M A thesis, University of Otago, Dunedin.

Reed, A.W., 2004. Reed Book of Māori Mythology. Wellington: Reed Publishers.

Ryan, P.M., 2008. The Raupo Dictionary of Modern Māori. Auckland: Penguin Group.

Sadler, Hone, pers. comm. 2013.

2014. Ko Tautoro Te Pito o Toku Ao: A Ngapuhi Narrative. New York: Auckland University Press Book.

Skinner, Damian, 2016. The Mãori Meeting House Introducing the Whare Whakairo. Wellington: Te Papa Press.

Sundt, Richard A., 2010. Whare Karakia: Māori Church Building, Decoration \& Ritual in Aotearoa New Zealand, 1834-1863. Auckland: Auckland University Press.

Taepa, Rev. Hohepa, 1966. The Rangiatea Story. Levin: Vestry of Rangiatea.

Taiapa, Pine, 1965. Interview regarding Rongomaitapui Meeting House, Te Araroa. N. Ellis Archive, Auckland.

Taylor, Rev. Richard, 1855. Te Ika a Maui: Or, New Zealand and its Inhabitants. Wellington: Wortheim and Macintosh.

Tikao, Taare T., 2004 [1939]. Tiakao Talks: Traditions and Tales told by Teone Taara Tikaoto Herries Beattie, Christchurch: Cadsonbury Publications.

Treadwell, Jeremy, 2012. Elevating the tāhuhu: An historical reconstruction. In S. King, A. Chatterjee and S. Loo (eds), Proceedings of 'Fabulation, Myth Nature and Heritage', 29th Conference of the Society of Architectural Historians of Australia and New Zealand, Launceston, July 5-8, 2012. Launceston, Australia: SAHANZ. Electronic publication, pp. 1151-1166.

2015a. Cook Islands architecture: The tradition. In R. Dixon, L.Crowl and M. Tuainekore (eds), Cook Islands Art and Architecture. [Suva], Fiji: USP Press, pp. 324-38.

2015b. Unexpected gusts and digital reconstruction: The re-buildings of Tāne Whirinaki. Fabrications: Journal of the Society of Architectural Historians, Australia and New Zealand 25 (1): 26-48.

Treadwell, Sarah, 1995. European Representations of the Architecture of Rangiatea. Unpublished PhD thesis, University of Auckland, Auckland.

Tuzin, Donald F., 1980. The Voice of the Tambaran: Truth and Illusion in Ilahita Arapesh Religion. Berkeley: University of California Press.

Waka Huia, 2014. Series 9, Episode 19. November. Auckland: TVNZ.

Walker, Ranginui, 2007. Ōpōtiki-Mai Tawhiti Capital of Whakatōhea. Auckland: Penguin Books.

2008. Tohunga Whakairo: Paki Harrison: The Story of a Master Carver. Auckland: Penguin Books.

Williams, Rev. Herbert Williams, 1896. The Maori Whare: Notes on the construction of a Maori house. Journal of the Polynesian Society 5 (3): 145-54. 
Williams, Rev. William Leonard, 1871. A Dictionary of the New Zealand Language: To Which is Added a Selection of Colloquial Sentences. London: Williams and Norgate.

1892. Dictionary of the New Zealand Language. London: Williams and Norgate.

\begin{abstract}
Māori construction and structural principles have received limited detailed attention since Reverend Herbert W. Williams published The Maori Whare: Notes on the Construction of a Maori House in this journal in 1896. Since then, publications that have considered Māori construction have relied heavily on this text. Subsequent discussion of Māori construction has examined 19th-century practices largely through Western historical and technical perspectives. This paper discusses Māori building concepts and technology from a bicultural viewpoint, involving both Māori tectonics and cosmology, and Western engineering principles. In doing so it draws from a close scrutiny of whare 'house' components, written and oral accounts of Māori cosmology and building, and from the analysis of large-scale structural models. The article focuses on the tāhuhu 'ridgepole' as a principal component of Māori architecture that activates both the primary cosmological structure of Te Ao Mārama 'creation narrative' and the structural system of the 19th-century Māori house. It is argued that the tāhuhu in its metaphorical manifestation as the atua 'god' Tāne (within Te Ao Mārama) corresponds in the construction of the whare with the holding up of the roof, understood as Ranginui, the sky father. Monumental in scale and ancestry, the tăhuhu mobilised a cooperative social dimension to its deployment in the whare, co-opting manpower from hapu and $i w i$ 'subtribal and tribal groups'. The paper concludes that the tâhuhu was a key element in a sophisticated and high performing Pacific building technology that was, in many ways, antithetical to Western building principles. Located in the abstract and conceptual distance of machine function, Western analysis appears to have failed to identify and understand the effective capacity of socially-collective Polynesian engineering.
\end{abstract}

Keywords: Māori whare (house), indigenous architecture, tāhuhu (ridgepole), Māori cosmology, New Zealand architecture

\title{
CITATION AND AUTHOR CONTACT DETAILS
}

Treadwell, ${ }^{1}$ Jeremy, 2017. Cosmology and structure: The tāhuhu in the 19th-century whare Māori. Journal of the Polynesian Society 126 (1): 93-122. DOI:http://dx.doi. org/10.15286/jps.126.1.93-122

${ }^{1}$ Correspondence: School of Architecture and Planning, University of Auckland, Private Bag 92019, Auckland, New Zealand. Email: j.treadwell@auckland.ac.nz 